\title{
Production of Glutamic acid using whole and immobilised cells of Corynebacterium glutamicum
}

\author{
Prasad M. Patil ${ }^{1}$, Nikhil Gupta ${ }^{1}$, Hipal Gaudani ${ }^{1}$, Mayank Gupta ${ }^{1}$, Girish Gupta ${ }^{1}$, Vamsi Krishna \\ $\mathbf{K}^{1}$, Soham Trivedi ${ }^{1}$, Megha Londhe ${ }^{2}$ \\ ${ }^{1}$ Department of Biotechnology, Padmashree Dr. D.Y. Patil University, Navi Mumbai, 400614, India \\ ${ }^{2}$ Department of Biotechnology, Padmashree Dr. D. Y. Patil University, Pune, India
}

\begin{abstract}
The strain of Corynebacterium glutamicum was tested on nutrient agar plate for its purity. This strain was further used for glutamic acid production under optimum growth conditions. Studies revealed that whole cells produce more glutamic acid compared to immobilized cells. It was also observed that among immobilized cells agarose produces more glutamic acid as compared to alginate. It was concluded that immobilized cells are more beneficial that whole cells as they are reusable and avoids chances of contamination hence cost effective.
\end{abstract}

\section{Introduction}

The research and development, carried out mainly in japan resulted in the successful and economical production of L-glutamic acid by the fermentative process. The significance of the establishment of microbial production of L-glutamic acid can not be overestimated. Such essential metabolites as amino acids were considered not to be accumulated in microbial culture due to regulatory mechanism in the cell[1]. The discovery of L-glutamic acid fermentation stimulated a wide variety of research aimed at the isolation of wild strains and the genetic derivation of mutant which could accumulate large amounts of primary metabolites. Glutamic acid producing cells e.g. biotin limited cells, penicillin or Tween 60 treated cells, oleic acid limiting cells, excreted intracellular Lglutamic acid when they were washed with phosphate buffer. On the other hand, biotin rich cells did not excrete endogenous Lglutamic acid when washed with the buffer. It was clarified that the cells, whose biotin content was greater than $0.5 \mathrm{ng} / \mathrm{mg}$. of the cell, biosynthesized sufficient amount of oleic acid, which resulted in high content of phospholipids in the cell membrane, these cells excreted endogenous glutamic acid poorly [2, 3].

Immobilization of whole cells:

Immobilization of microbial cells in biological processes can occur either as a natural phenomenon or through artificial process. While the attach cells in the natural habitat exhibit significant growth, the artificially immobilized cells are allowed restructure growth. Since the time, first reports of successful applications of immobilized cells in industrial applications, several research groups world over have attempted wholecells immobilization as a viable alternative to conventional microbial fermentation. Various immobilization protocol and numerous carrier materials were tried. The cell immobilization process has also triggered our interest in bioreactor design. Using immobilized cells, different bioreactor configuration were reported with variable success. The study on the physiology on immobilized cells and development of noninvasive measuring technique have remarkably improve our understanding on microbial metabolism under immobilized state. Many methods namely adsorption, covalent bonding, cross linking, entrapment and encapsulation are widely used for immobilization. These categories are commonly used in immobilized enzyme technology. However, due to completely different size and environmental parameters of the cells, the relative importance of these methods is considerably different. The criteria imposed for cell immobilization technique usually determine the nature of the application [4].

\section{Plan of Action}

1. Cultivation of bacteria on petri plate contain agar medium

2. Prepare a seed medium.

3. From seed medium prepare

Production medium of whole cells, Production of medium of immobilised cells (immobilization is done by entrapment media)

4. from broth culturepH, Sugar content, ammonia content estimated METHODOLOGY

\section{Nutrient agar:}

It was used for the growth of the species. During the preparation, components involved are peptone, yeast extract, agar and distilled water.

\section{Seed media for Corynebacterium} glutamicum

The media containing Glucose, Potassium hydrogen Ortho phosphate, Magnesium sulphate, Yeast extract, Urea and Distilled water was used.

Preparation of production medium (for glutamic acid)

The media containing Glucose, Ammonium sulphate, Potassium dihydrogenPhosphate, Magnesium sulphate, Potassium sulphate, Ferrous sulphate, 
Manganese sulphate, Biotin, Distilled water.

\section{Preparation of Anthrone reagent}

We prepared the Anthrone reagent by dissolving $200 \mathrm{mg}$ anthrone in $100 \mathrm{ml}$ of ice cold $95 \%$ sulphuric acid. Standard glucose stock, Dissolved $100 \mathrm{mg}$ glucose in $100 \mathrm{ml}$ distilled water. Working standard glucose stock- $10 \mathrm{ml}$ of standard glucose stock diluted to $100 \mathrm{ml}$ with distilled water, store in freeze.

\section{Method for sugar estimation}

We used glucose stock solution in varying concentration from $0,0.2,0.4 \ldots . .1(\mathrm{ml})$ and made the volume $1 \mathrm{ml}$ with distilled water. Added $4 \mathrm{ml}$ of freshly prepared anthrone reagent in each sample. It was kept in a boiling water bath for 8-10 min. and cooled rapidly to room temperature. O.D was taken at $630 \mathrm{~nm}$. Standard graph by taking concentration $(\mathrm{ml})$ on X- axis Vs O.D (630 $\mathrm{nm}$ ) on $\mathrm{Y}$-axis was plot.

\section{For ammonia estimation}

Take ammonium sulphate stock solution in varying concentration from $0,0.1,0.2 \ldots 1$ $(\mathrm{ml})$. and make up the volume to $1 \mathrm{ml}$ with distilled water.

Add $1 \mathrm{ml}$ of Nesslers reagent to each sample. Take O.D at $500 \mathrm{~nm}$.

Plot standard graph by taking concentration (ml) on X-axis Vs O.D (500 nm) on Y-axis.

\section{For immobilization of whole cells}

The chemicals used were Sodium-Alginate \& Agarose.

Method-

\section{Sodium alginate}

$2 \mathrm{~g}$ sodium alginate is dissolved in $100 \mathrm{ml}$ $0.9 \% \mathrm{NaCl}$; if necessary the solubilization can be speeded up by warming the solution gently, on know account should it be allowed to boil! The solution is then autoclaved for no longer than $15 \mathrm{~min} .10 \mathrm{ml}$ of inoculum is added to the solution prepared in step 1.

The $\mathrm{Na}$ alginate solution is then added drop wise (e.g. with a burette) with stirring to a $0.1 \mathrm{M} \mathrm{CaCl} 2$ solution. The gel beads formed are left in solution for $1 \mathrm{hr}$. before being filtered off. The beads are then stirred in a $0.9 \% \mathrm{NaCl}$ per $50 \mathrm{mM} \mathrm{CaCl} 2$ solution for 20 min. to allow the diffusion of access calcium. The washed, the cell-coated beads are now ready for use.

\section{Agarose}

$0.3 \mathrm{~g}$ of agarose is dissolved in $30 \mathrm{ml}$ of TAE buffer by boiling till a clear solution is obtained.

$5 \mathrm{ml}$ of inoculum is added in above TAE buffer. The solution is added in drop wise (e.g. with a micro pipette) in ice cold ethanol. The gel beads formed are ready for use.

\section{Chromatography}

We used this technique separation of amino acids by 2D- dimensional paper chromatography.

\section{Observation}

1. Testing of Corynebacterium glutamicum for glutamic acid production From the incubated nutrient agar slant of Corynebacterium glutamicum, loopful of culture was inoculated in the petriplate containing nutrient agar medium. This petriplate was kept for incubation at $37{ }^{\circ} \mathrm{C}$ for the two days after two days incubation colonies of C.glutamicum was observed on petriplate.

\section{Inoculum production}

From the nutrient agar plate containing colonies of C.glutamicum, a loopful of culture was inoculated in to seed media and kept in shaker incubator at $30{ }^{\circ} \mathrm{C}, 120 \mathrm{rpm}$ for two days. After two days of incubation turbidity was observed in seed media.

3. Effect whole and immobilised cells on production of glutamic acid production

From the seed medium $5 \mathrm{ml}$ of inoculums inoculated in production medium. Kept in shaker at $32{ }^{\circ} \mathrm{C}, 130 \mathrm{rpm}$ for six days. Cells are immobilised using alginate by the method of entrapment and inoculated in production medium. It was observed that the concentration of sugar decreases. Increase in conc. of ammonia is more in whole cells as compare to alginate indicate that whole cells produce more glutamic acid as compare to alginate.

\section{Effect of $\mathrm{pH}$}

$\mathrm{pH}$ of the production medium was 7.2 and this $\mathrm{pH}$ becomes acidic and attains value nearly 3.5-4 which indicate that acid production occur in the medium.

\section{Discussion}

We have study, the effect of whole and immobilised cells on the production of glutamic acid. Whole cells produces more glutamic acid as compare to immobilised at $32{ }^{\circ} \mathrm{C}, 100 \mathrm{rpm}$, as whole in direct contact with liquid medium but immobilised cells are entrapped in polymer matrices like $\mathrm{Na}$ alginate ,also the highest concentration of ammonia in whole cells indicate that the whole cells producer more glutamic acid as compare to immobilised cells. Corynebacterium glutamicum has produced high yield of glutamic acid. The confirmation of glutamic acid separation was done by paper chromatography technique. Use of alginate for immobilisation is more popular as it requires mild condition and simplicity of used procedure. Glutamic acid has wide 
application in medicine, food industries, pharmacology etc. Large scale production of glutamic acid using immobilised cells is preferred as immobilised cells are reusable, it is not necessary to produce inoculum every time, it avoids chance of contamination, hence saves time and cost effective. It is found that C-source, culture condition and biotin concentration are important parameters in glutamic acid production and further studies are require in order to search for extraction and purification of glutamic acid production medium on laboratory scale.

\section{References}

[1] Peppler H. J. and Perlman (2004) microbial technology/2ed $\mathrm{Vol} 1$, academic press, New York.

[2] Takinami K., Yamada K., and Okada $\mathrm{H}$. (1966) agric. Biol. Chem 30, 674.

[3] Takinami K., Yamada K., and Okada H. (1967) agric. Biol. Chem 31, 223.

[4] Ikeda K. (1908) J. Tokyo chem. Soc. 30, 820.

[5] Kinoshita S., Udaka S., and Shimmo M. (1957) J. Gen. Appl. Microbial. 3, 193.
[6] Tanaka K., Iwaski T. and Kinoshita S $(1960)$ J. Agric. Chem. Soc. Jpn. 34, 593.

[7] Shiio I. Ostuka S. and Katsuya N. (1963) J. Biochem. (Tokyo) 53 , 333

[8] Breuer L. H., Pond W.G., Warner R.G. and Loosli J. K. (1964) J. Natr. 82,499 .

[9] Oishi K. (1967) J, Argic. Chem, Soc, Jpn $41, \mathrm{R} 35$.

[10]Shibukawa M. , Kurima M. , Okabe S. and Osawa T. (1968) Hakko. To Taisha 17, 61.

[11]Izumi Y., Tani Y. and Ogato K. (1973) Biochem. Biophys. Acta 326, 485.

[12]Kamiryo T., Parthasurathy S. and Numa S. (1976) Proc. Natl. Acad. Sci. U. S. A. 73, 386.

[13]Mendel M. and Hinga A. (1976) J. Mol Biol, 53, 159.

[14]Duncan C. H., Wilson, G. A. and Young, F. E. -, Gene 1, 153 (177)

[15]Chang S. and choen S. N. (1979) Molec, Gen. Genet., 168, 111.

[16]Hinnen A., Hicks J.B. and Fink G.R. (1978) proc. Natl, Sci., USA, 75, 1929. 
Table : 1 Standard graph for ammonia estimation

\begin{tabular}{|l|l|l|l|l|}
\hline $\begin{array}{l}\text { Stock solution in } \\
\mathrm{ml}\end{array}$ & $\begin{array}{l}\text { Distilled water in } \\
\mathrm{ml}\end{array}$ & $\begin{array}{l}\text { Concentration } \\
\mathrm{mg} / \mathrm{ml}\end{array}$ & $\begin{array}{l}\text { Nesslers reagent } \\
\text { in ml }\end{array}$ & $\begin{array}{l}\text { O.D. at } \\
500 \mathrm{~nm}\end{array}$ \\
\hline 0.1 & 0.9 & 0.2 & 1 & 0.005 \\
\hline 0.2 & 0.8 & 0.4 & 1 & 0.153 \\
\hline 0.3 & 0.7 & 0.6 & 1 & 0.265 \\
\hline 0.4 & 0.6 & 0.8 & 1 & 0.353 \\
\hline 0.5 & 0.5 & 1.0 & 1 & 0.447 \\
\hline 0.6 & 0.4 & 1.2 & 1 & 0.531 \\
\hline 0.7 & 0.3 & 1.4 & 1 & 0.573 \\
\hline 0.8 & 0.2 & 1.6 & 1 & 0.650 \\
\hline 0.9 & 0.1 & 1.8 & 1 & 0.713 \\
\hline 1.0 & 0.0 & 2.0 & 1 & 0.847 \\
\hline
\end{tabular}

Table : 2 Standard graph for sugar estimation

\begin{tabular}{|c|c|c|c|c|}
\hline $\begin{array}{l}\text { Stock solution in } \\
\mathrm{ml}\end{array}$ & $\begin{array}{l}\text { Distilled water in } \\
\mathrm{ml}\end{array}$ & $\begin{array}{l}\text { Anthrone reagent } \\
\text { in } \mathrm{ml}\end{array}$ & \multirow{6}{*}{$\begin{array}{l}\text { Keep in boiling } \\
\text { water bath for } 10 \\
\text { mins. }\end{array}$} & O.D. at $630 \mathrm{~nm}$ \\
\hline 0.2 & 0.8 & 4 & & 0.331 \\
\hline 0.4 & 0.6 & 4 & & 0.612 \\
\hline 0.6 & 0.4 & 4 & & 0.980 \\
\hline 0.8 & 0.2 & 4 & & 1.280 \\
\hline 1.0 & 0.0 & 4 & & 1.513 \\
\hline
\end{tabular}

Table : 3 Concentration of ammonia in culture media Whole cells

\begin{tabular}{|l|l|l|}
\hline Days & O.D. at $500 \mathrm{~nm}$ & Concentration $\mathrm{in} \mathrm{mg} / \mathrm{ml}$ \\
\hline Media & 0.231 & 0.520 \\
\hline 1 & 0.393 & 0.884 \\
\hline 2 & 0.615 & 1.383 \\
\hline 3 & 0.734 & 1.651 \\
\hline 4 & 0.803 & 1.807 \\
\hline 5 & 0.982 & 2.210 \\
\hline 6 & 1.219 & 2.722 \\
\hline
\end{tabular}

Table : 4 Concentration of ammonia in culture media Immobilized cells (alginate)

\begin{tabular}{|l|l|l|}
\hline Days & O.D. at $500 \mathrm{~nm}$ & $\mathrm{~g} / \mathrm{ml}$ COncentration in \\
\hline Media & 0.231 & 0.520 \\
\hline 1 & 0.353 & 0.794 \\
\hline 2 & 0.547 & 1.230 \\
\hline 3 & 0.676 & 1.521 \\
\hline 4 & 0.725 & 1.631 \\
\hline 5 & 0.834 & 1.877 \\
\hline 6 & 1.019 & 2.293 \\
\hline
\end{tabular}

Table : 5 Concentration of sugar in culture media Whole cells

\begin{tabular}{|l|l|l|}
\hline Days & O.D. at $630 \mathrm{~nm}$ & Concentration $\mathrm{in} \mathrm{mg} / \mathrm{ml}$ \\
\hline Media & 0.693 & 0.418 \\
\hline 1 & 0.617 & 0.372 \\
\hline 2 & 0.494 & 0.297 \\
\hline 3 & 0.459 & 0.276 \\
\hline 4 & 0.382 & 0.230 \\
\hline 5 & 0.321 & 0.193 \\
\hline 6 & 0.270 & 0.162 \\
\hline
\end{tabular}


Table : 6 Concentration of sugar in culture media Immobilized cells (alginate)

\begin{tabular}{|l|l|l|}
\hline \multicolumn{1}{|c|}{ Days } & O.D. at $630 \mathrm{~nm}$ & Concentration in $\mathrm{mg} / \mathrm{ml}$ \\
\hline Media & 0.693 & 0.418 \\
\hline 1 & 0.631 & 0.380 \\
\hline 2 & 0.520 & 0.313 \\
\hline 3 & 0.479 & 0.288 \\
\hline 4 & 0.428 & 0.258 \\
\hline 5 & 0.363 & 0.218 \\
\hline 6 & 0.301 & 0.181 \\
\hline
\end{tabular}

Table : $7 \mathrm{pH}$ - Range

\begin{tabular}{|l|l|l|}
\hline Days & Whole cells & Alginate \\
\hline Media & 7.2 & 7.2 \\
\hline 1 & 6.5 & 6.9 \\
\hline 2 & 5.2 & 5.4 \\
\hline 3 & 4.8 & 5.0 \\
\hline 4 & 4.5 & 4.8 \\
\hline 5 & 4.1 & 4.4 \\
\hline 6 & 3.9 & 4.0 \\
\hline
\end{tabular}

OD Vs ammonia concentration

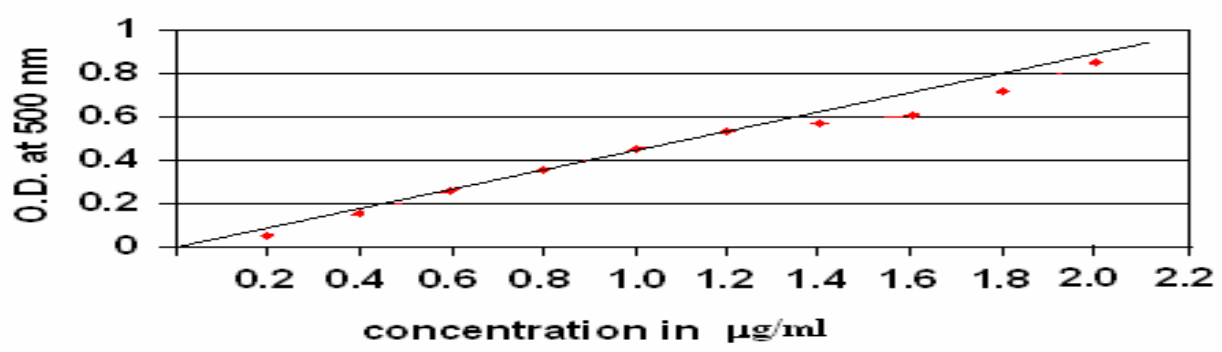

Fig 1. Standard graph for ammonia

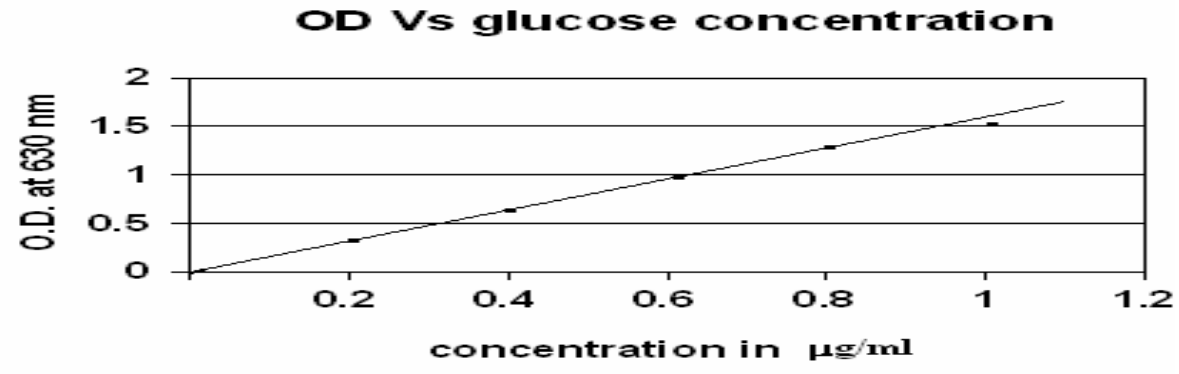

Fig 2. Standard graph of glucose

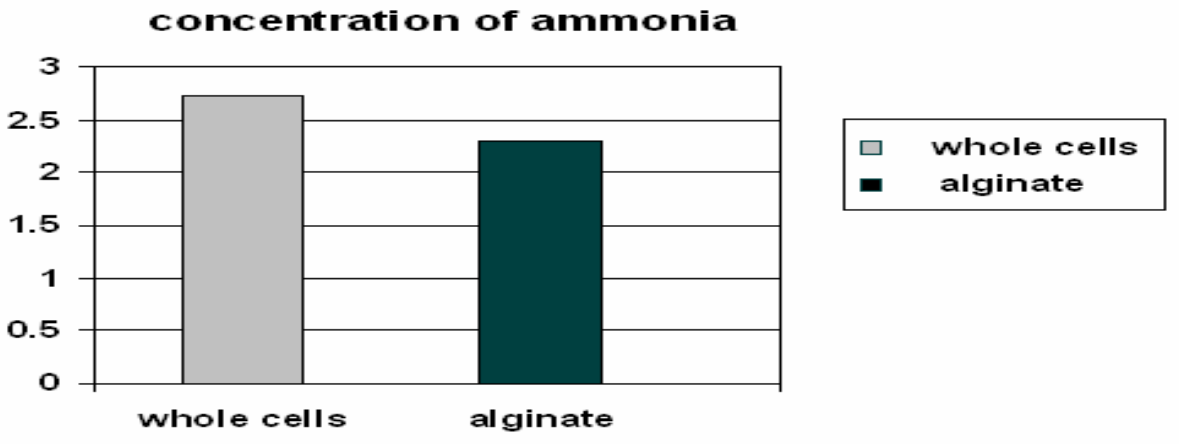

Fig 3. Group showing concentration of ammonia $(\mathrm{mg} / \mathrm{ml})$ on day 6 in production medium of glutamic acid 


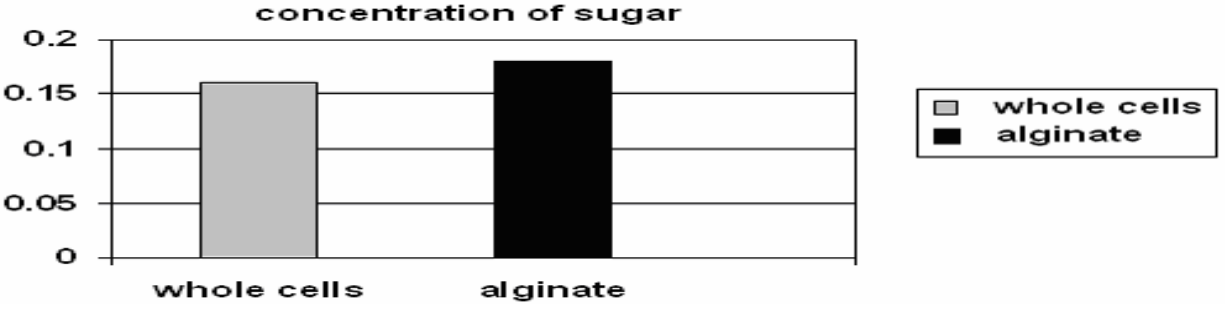

Fig 4. Group showing concentration of sugar $(\mathrm{mg} / \mathrm{ml})$ on day 6 in production medium of glutamic acid

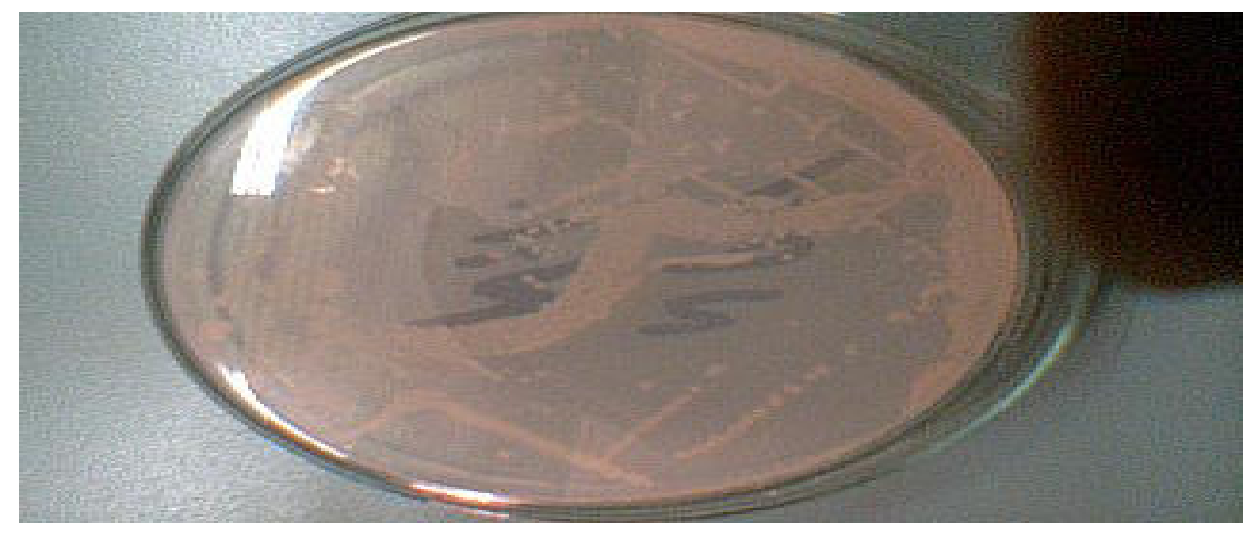

Fig 5. Plating of microorganism on agar plate by four square method

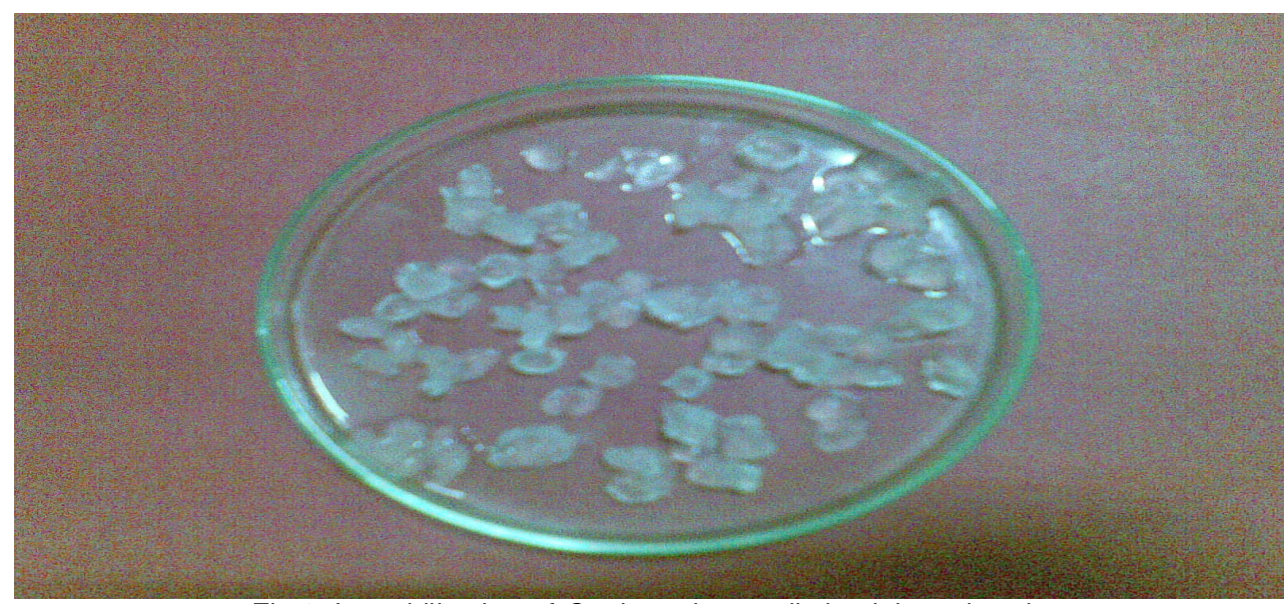

Fig 6. Immobilization of C. glutamicum cells in alginate beads

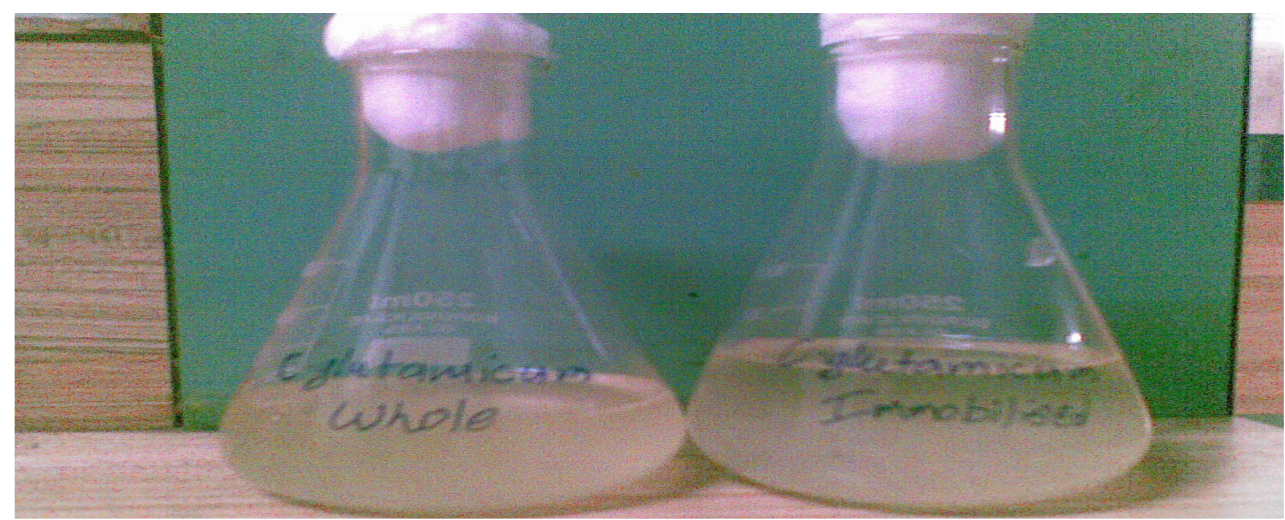

Fig 7. Culture of whole and immobilized cells 